\title{
Sosialisasi Penerapan Pola Hidup Bersih bagi Anak Sekolah Menghadapi Pandemi Covid-19 di Kabupaten Kepulauan Meranti - Riau
}

\author{
https://doi.org/10.25008/parahita.v1i2.46
}

\author{
Welly Wirman $^{1^{*}}$, Ringgo Eldapi Yozani ${ }^{2}$, Tutut Ismi Wahidar ${ }^{3}$, Ikhma Zurani ${ }^{4}$ \\ 1,2,3,4 Universitas Riau \\ Jl. Hr. Soebrantas Km 12,5 Pekanbaru 28293 - Indonesia \\ *Email Korespondensi: welly.wirman@,lecturer.unri.ac.id
}

\begin{abstract}
Abstrak - Kabupaten Kepualauan Meranti mengalami lonjakan kenaikan kasus pasien Covid-19 sebesar enam kasus per19 Juni 2020 dari sebelumnya hanya tercatat satu orang terpapar Covid19. Sebelumnya Kepulauan Meranti, Riau dianggap sebagai zona hijau. Data di lapangan menunjukkan sekolah-sekolah diliburkan karena lonjakan kasus Covid-19 tersebut. Sebagai wilayah kepulauan, penyebaran Covid-19 dikhawatirkan akan menyebar sangat cepat jika tidak ditangani dengan segera, khususnya pada anak-anak dan lansia. Pengabdian kepada Masyarakat ini bertujuan mensosialisasikan penerapan pola hidup bersih dan sehat bagi anak-anak usia sekolah di masa pandemik melalui pendekatan belajar sambil bermain. Pengabdian ini membuat video pengetahuan dan tata pola hidup sehat selama pandemi dalam bentuk mini video kartun. Hasil di lapangan menunjukkan, video yang diberikan ke-30 sekolah di Kabupaten Kepulauan Meranti mendapat sambutan dan antusias dari anak-anak. Video pola hidup sehat selama pandemik tersebut juga sudah disebarkan dan dijadikan bahan tontonan oleh orangtua untuk anak-anak di rumah.
\end{abstract}

Kata Kunci: Covid-19, anak-anak, video, hidup sehat, siswa sekolah

\section{PENDAHULUAN}

Kasus Covid-19 di Kabupaten Kepulauan Meranti, Riau cukup tinggi di bulan Juni 2020. Sebelumnya masyarakat yang terkena Covid 19 di kabupaten ini dan dinyatakan sembuh hanya satu orang, sehingga Kabupaten Kepulauan Meranti dinyatakan zona hijau. Belakangan, pasien terpapar corona bertambah enam kasus per tanggal 19 Juni 2020. Dengan penambahan kasus baru itu, pemerintah daerah harus berusaha keras mengatasinya dan dalam membuat kebijakan untuk meminimalisir kasus tersebut. Salah satunya dengan membuat Pilot Project Kampung Tangguh Nusantara di tiap kecamatan (Imroen Ali, 2020).

Kabupaten Kepulauan Meranti merupakan kabupaten termuda di Riau dengan ibukota Selat Panjang. Kabupaten ini terdiri dari Pulau Tebing Tinggi, Pulau Padang, Pulau Merbau, Pulau Ransang, Pulau Topang, Pulau Manggung, Pulau Panjang, Pulau Jadi, Pulau Setahun, Pulau Tiga, Pulau Baru, Pulau Paning, Pulau Dedap, Pulau Berembang, Pulau Burung. Kabupaten Kepulauan Meranti merupakan pemekaran dari Kabupaten Bengkalis dan dibentuk 19 Desember 2009 berdasarkan UU No. 12 tahun 2009.

Kota Selat Panjang merupakan pusat pemerintahan Kabupaten Kepulauan Meranti. Dulu, kota itu merupakan bandar (kota) yang paling sibuk dan terkenal sebagai pusat perniagaan Kesultanan Siak. Di bandar itu sejak dahulu telah terbentuk masyarakat heterogen, terutama suku Melayu dan Tionghoa. Interaksi antaretnis dalam masyarakat telah membentuk keharmonisan kegiatan kultural maupun perdagangan di Selat Panjang (Pemkab Meranti, 2020).

Sebagai wilayah kepulauan, Kabupaten Kepulauan Meranti merasa penyebaran Covid-19 akan lebih cepat menyebar dibandingkan wilayah lain di Provinsi Riau. Hal itu terungkap dari wawancara dengan Bupati Kabupaten Kepulauan Meranti, Irwan Nasir, 20 Juni 2020. "Kami khawatir dengan penyebaran Covid ini terutama untuk anak-anak, ibu 
hamil dan orangtua. Orangtua biasanya agak keras kepala. Ibu hamil karena rentan, dan anak-anak karena sifat jiwanya yang masih senang bermain dan tidak betah dikurung di rumah, tentu lebih beresiko," katanya.

Berdasarkan hasil wawancara tersebut ditambah pengamatan awal di lapangan, pasca terdeteksinya enam kasus per 19 Juni 2020, sekolah-sekolah baru diliburkan. Demi membantu Kabupaten Kepulauan Meranti dalam mensosialisasikan new normal life dan pola hidup bersih dan sehat, maka pengabdian kepada masyarakat ini diselenggarakan.

Tujuan dari komunikasi penyuluhan yang diadakan ini adalah untuk mensukseskan program-program yang disampaikan kepada masyarakat. Selain itu untuk mengikuti saran Kepala Kepolisian Resort Meranti yang meminta dibuatnya pilot project kampung percontohan new normal life dan pola hidup bersih agar menjadi contoh bagi seluruh desa dan masyarakat di Kabupaten Kepulauan Meranti. Tim pengabdian lantas berinisiasi mensosialisasikan pola hidup bersih dan sehat pada anak-anak melalui metode belajar sambil bermain.

Kegiatan pengabdian kepada masyrakat ini menyasar masyarakat Kabupaten Kepulauan Meranti dengan sasaran para kepala sekolah mulai dari tingkat PAUD, TK, SD hingga SMP se Kabupaten Kepulauan Meranti. Dipilihnya para kepala sekolah dengan maksud dan tujuan agar mereka dapat melanjutkan sosialisasi mengenai new normal life dan Pola Perlaku Hidup Bersih dan Sehat tersebut ke setiap siswa di sekolahnya, sehingga informasi dapat menyebar lebih luas ke masyarakat Kabuaten Kepulauan Meranti.

\section{METODE PELAKSANAAN}

Program sosialisai penerapan hidup sehat bagi anak-anak di Kabupaten Kepulauan Meranti ini dilaksanakan dalam tiga tahap, yaitu tahap persiapan, tahap pelaksanaan dan tahap evaluasi kegiatan.

Tahap Persiapan, meliputi pertemuan dengan sesama tim pengabdian sosialisasi new normal life dan penerapan pola hidup bersih dan sehat di Kabupaten Kepulauan Meranti. Setelah itu mengadakan pertemuan dengan Bupati Kepulauan Meranti, Bapak Drs. Irwan Nasir, M.Si. Dalam pertemuan tersebut, Bupati menyambut baik kegiatan Tim Pengabdian yang dilaksanakan di Kabupaten Kepulauan Meranti.

Langkah selanjutnya, sesuai arahan Bupati, pengabdian diarahkan dengan target para kepala sekolah yang ada di Kabupaten Kepualaun Meranti. Untuk itu koordinasi lanjutan Tim Pengabdian berkoordinasi dengan Plt. Kepala Dinas Pendidikan Kabupaten Kepulauan Meranti, Syamsudin, SH, MH untuk membahas teknis pelaksanaan pengabdian tersebut.

Langkah berikutnya adalah mengumpulkan data dan informasi mengenai calon peserta. Audiens yang akan dijadikan dalam pelatihan ini adalah Kepala Sekolah dari tingkat PAUD, Taman Kanak-Kanak (TK), Sekolah Dasar (SD), dan Sekolah Menengah Pertama (SMP) se Kabupaten Kepulauan Meranti.

Selanjutnya diadakan identifikasi permasalahan yang terjadi. Permasalahan yang diidentifikasi berkaitan dengan sosialisasi mengenai new normal life serta Penerapan Pola Perilaku Hidup Bersih dan Sehat di Kabupaten Kepulauan Meranti. Hal ini bertujuan untuk memberikan pemahaman kepada masyarakat atas pentingnya penerapan new normal life dan pola perilaku hidup bersih untuk mencegah meluasnya penyebaran virus Covid 19 di Kabupaten Kepualauan Meranti.

Berikutnya adalah mempersiapkan peralatan dan bahan-bahan untuk melakukan kegiatan pengabdian kepada masyarakat ini. Peralatan dan bahan yang disiapkan adalah membuat Video Edukasi mengani Covid 19 yang direkam ke dalam Compact Disk (CD) untuk diberikan kepada peserta. Selanjutnya membuat masker yang akan dibagikan ke audiens sebagai kampanye penggunaan masker di masa pandemi Covid 19. 
Tahap Pelaksanaan, dilaksanakan 9 Oktober 2020 di gedung serba guna Kantor Bupati Kabupaten Kepulauan Meranti, dihadiri 30 orang perwakilan kepala sekolah, dan lima orang anggota satuan tugas Covid-19 Kabupaten Kepulauan Meranti.

Penyampaian materi berlangsung selama dua jam dengan teknis, pemaparan pola hidup sehat bagi anak-anak selama 40 menit, pemutaran video Covid-19 selama 15 menit, dan tanya jawab satu jam serta pembagian video Covid-19 dan masker kepada para peserta.

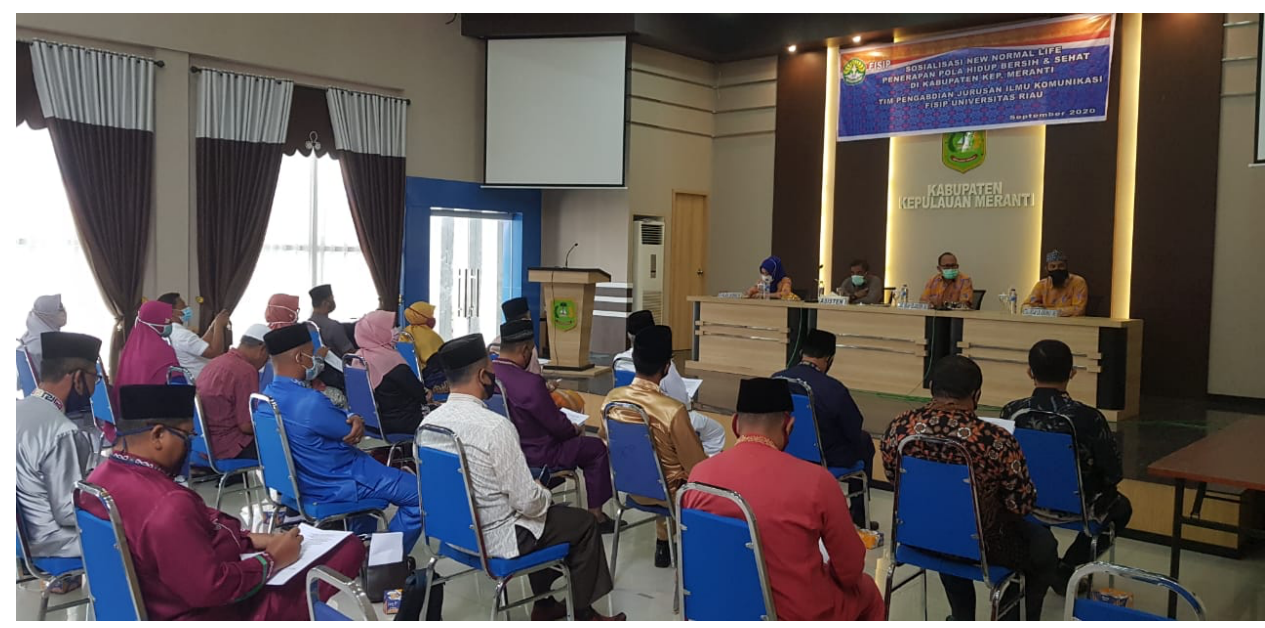

Gambar 1. Para kepala sekolah peserta sosialisasi

Tahap Evaluasi, dilaksanakan 20 Oktober 2020. Tim pengabdian melakukan wawancara dengan pihak sekolah, orangtua murid serta anak-anak yang menonton video tersebut. Tim pengabdian melakukan koordinasi dengan pemerintah daerah serta Satgas Covid-19 mengenai dampak sosialisasi untuk ditindaklanjuti agar semua warga memiliki video tersebut dan kemudian dijadikan sebagai bahan tontonan anak-anak di rumah.

\section{HASIL DAN PEMBAHASAN}

Tim Pengabdian menyusun materi pemaparan berisi bagaimana penerapan kehidupan tatanan baru (new normal life). Juga memberikan pemaparan kepada masyarakat atas pentingnya penerapan Pola Hidup Bersih dan Sehat (PHBS). Materi disampaikan oleh narasumber yang juga Ketua Tim Pengabdian Kepada Masyarakat, Dr. Welly Wirman, M.Si dan Dr. Ringgo Eldapi Yozani, M.I.Kom.

Tim Pengabdian kepada masyarakat berkolaborasi dengan Tim Pengabdian dari Fakultas Ilmu Komunikasi Universitas Islam Riau. Dalam pemaparannya, Tim Pengabdian Kepada Masyarakat Fakultas Ilmu Komunikasi Universitas Islam Riau memberikan pemamparan terkait proses pembelajaran dengan memanfaatkan tekhnologi. Materi tersebut disampaikan oleh Dr. Muh AR Imam Riauan, M.I.Kom.

Dalam paparannya Dr. Muh AR Imam Riauan mengatakan dampak positif dari proses pembelajaran dengan memanfaatkan tekhnologi di masa pandemi ini adalah membuat masyarakat baik guru dan murid serta orang tua menjadi melek tekhnologi pembelajaran.

Pemaparan materi dilakukan dengan metode sosialisasi dan diskusi. Tim Pengabdian memberikan materi berkaitan dengan tema yang telah ditetapkan dan masyarakat memberikan respon terhadap materi tersebut dengan tujuan terjadinya diskusi antara pemateri dengan audiens.

Menurut Soejono Dirdjosisworo dalam Prawiro (2020), sosialisasi mengandung tiga arti, yaitu: (1) Proses belajar, suatu proses akomodasi di mana individu menahan, 
mengubah impuls-impuls dalam dirinya dan mengambil cara hidup atau kebudayaan masyarakatnya; (2) Kebiasaan: dalam bersosialisasi setiap individu mempelajari kebiasaan, sikap, ide-ide, pola-pola nilai dan tingkah laku, dan ukuran kepatuhan tingkah laku di dalam masyarakat di mana ia hidup; (3) Sifat dan kecakapan: semua sifat dan kecakapan yang dipelajari dalam proses sosialisasi itu disusun dan dikembangkan sebagai suatu kesatuan dalam diri seseorang.

Dari sosialisasi yang dilakukan, diharapkan pengetahuan bagi masyarakat akan bertambah pengetahuan tentang tatanan kehidupan baru (new normal life), dan penerapan pola hidup bersih yang diharapkan dapat menjadi kebiasaan untuk memutus mata rantai penyebaran virus Covid 19.

Sosialisasi dilakukan dengan metode komunikasi penyuluhan. Penyuluhan merupakan usaha menyebarluaskan hal-hal yang baru agar masyarakat tertarik dan berminat untuk melaksanakannya dalam kehidupan sehari-hari. Penyuluhan juga merupakan kegiatan mendidik masyarakat, memberi mereka pengetahuan, informasiinformasi, dan kemampuan-kemampuan baru agar mereka dapat membentuk sikap dan berperilaku hidup menurut apa yang seharusnya.

Penyuluhan pada hakekatnya merupakan suatu kegiatan pendidikan nonformal dalam rangka mengubah masyarakat menuju keadaan yang lebih baik seperti. Dalam upaya mengubah masyarakat tersebut, terdapat unsur-unsur seperti gagasan/ide/konsep yang dididikkan, lembaga/badan/pihak yang memprakarsai perubahan masyarakat secara keseluruhan, tenaga penyebar ide/konsep yang dimaksud, dan anggota masyarakat baik secara individu maupun secara keseluruhan yang menjadi sasaran dari kegiatan penyuluhan (Rasyid Anuar, 2011).
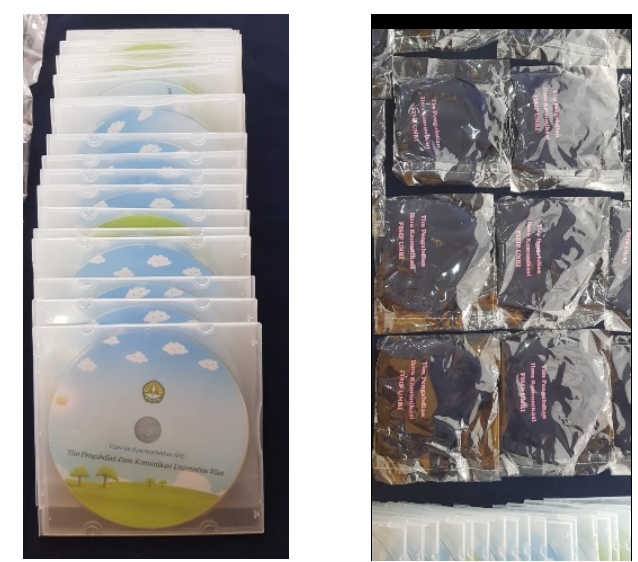

Gambar 2. Video dan masker yang dibagikan kepada Audiences

\section{KESIMPULAN}

Dari evaluasi yang dilakukan melalui tanya jawab terhadap para peserta, diperoleh kesimpulan materi yang disampaikan telah memberikan manfaat bagi para peserta, diantaranya: (1) bertambahnya pemahaman mengenai penerapan new normal life dan penerapan pola hidup bersih dan sehat untuk mencegah dan memutus mata rantai penyebaran Covid 19 di Kabupaten Kepulauan Meranti; (2) sosialisasi yang diberikan telah berhasil memberi pemahaman kepada peserta agar menerapkan tatanan new normal life dan tatanan pola hidup bersih dan sehat di Kabupaten Kepulauan Meranti.

Tim pengabdian berharap kegiatan ini dapat menumbuhkan motivasi dan semangat untuk lebih aktif dan berpartisipasi dalam mengkampanyekan tatanan kehidupan baru dan penerapan pola hidup bersih dan sehat. Selain itu juga dapat membantu pemerintah daerah untuk memutus mata rantai penyebaran Covid 19 di Kabupaten Kepulauan Meranti. 


\section{Ucapan Terimakasih}

Tim pengabdian mengucapkan terimakasih kepada pihak-pihak yang mendukung terwujudnya program sosialisasi hidup bersih dan sehat di Kabupaten Kepulauan Meranti: Pemerintah Daerah Kabupaten kepulauan Meranti, Kepala-kepala sekolah yang hadir, Universitas Riau, khususnya Dekan Fakultas Ilmu Sosial dan Ilmu Politik, Dr. Syafri Harto, M.Si yang menyetujui program ini.

\section{Daftar Pustaka}

Imroen, Ali. (2020). Kasus Corona di Kepulauan Meranti Meledak, Enam Warga Terkonfirmasi Positif. p. 1. Retrieved from https://www.halloriau.com/read-meranti130125-2020-05-19-kasus-corona-di-kepulauan-meranti-meledak-enam-wargaterkonfirmasi-positif.html

Pemkab Meranti. (2020). Sejarah Kabupaten Kepulauan Meranti. Retrieved June 25, 2020, from http://news.merantikab.go.id/web/profil/sejarah

Prawiro, M. (2020). Pengertian Sosialisasi: Arti, Tujuan, Fungsi, Media, dan Contoh Sosialisasi. Retrieved from https://www.maxmanroe.com/vid/sosial/pengertiansosialisasi.html

Rasyid, Anuar. (2011). Komunikasi Penyuluhan. Pekanbaru: Pusat Pengembangan Pendidikan Universitas Riau. 